\title{
ALKALINE PHOSPHATASE ACTIVITY ASSESSMENT OF TWO ENDODONTIC MATERIALS: A PRELIMINARY STUDY
}

S. Rajan, H. Awang, S. Devi, A.H. Pooi, H. Hassan. Alkaline phosphatase activity assessment of two endodontic materials: A preliminary study. Annal Dent Univ Malaya 2008; 15(1): 5-10.

\section{ABSTRACT}

Objective: An in vitro assessment of MG-63 human osteosarcoma cells' alkaline phosphatase (ALP) activity when in contact with calcium hydroxide powder $(\mathrm{CH})$, paste $(\mathrm{CHP})$ and grey mineral trioxide aggregate (MTA).

Methods: MG-63 cells were seeded to the three selected materials for durations of $0.25,0.5,1,24$, 48 and 72 hours. BCIP-NBT assay was used and ALP activity quantified using ELISA reader at 410 nm.

Results: The overall analysis for ALP activity indicated significant interaction between test materials and control (maintenance medium). Subsequently, the test materials were paired and analysed for initial $(0.25,0.5,1$ hour $)$ and delayed response (24, 48 and 72 hours). During the initial response, $\mathrm{CH}$ exhibited an increased ALP activity compared to MTA. This interaction was not dependant on duration. The delayed response exhibited elevated ALP activity with CHP when compared to MTA and $\mathrm{CH}$. The interaction of CHP was dependant on duration.

Conclusion: All three materials exhibited increased ALP activity.

Key words: MTA, calcium hydroxide, alkaline phosphatase, in vitro assessment, MG-63 cell line

\section{INTRODUCTION}

Endodontic treatment is greatly complicated in nonvital immature permanent teeth. Pulp necrosis may occur at any stage of root development. The tooth would have an open apex and root apex may be divergent, parallel-shaped or convergent (1). In any event, the treatment of choice is apexification, whereby an osteoinductive material is placed into the root canal to induce hard tissue barrier formation at the root apex.

There are two types of apexification, conventional and one visit type. In conventional apexification, an osteoinductive material is placed into the canal and replaced periodically until a hard tissue barrier is formed. This process may take between 13-67weeks (2). The long duration needed for treatment and repeated replacement of canal
Original Article

S. Rajan'1, H. Awang1, S. Devi ${ }^{2}$,
A.H. Pooi ${ }^{3}, \mathrm{H}$. Hassan ${ }^{2}$
${ }^{1}$ Department of Children's Dentistry \& Orthodontics,
Faculty of Dentistry, University of Malaya,
50603 Kuala Lumpur, Malaysia.
Tel: 79674540
Email: ${ }_{\text {rsadna(d) um.edu.my }}$
${ }^{2}$ Department of Medical Microbiology,
${ }^{3}$ Institute of Mathematical Science,
Corresponding author: Sadna Rajan

medicaments would have implications on strength of tooth (3). In addition, patient's motivation and compliance plays important role in treatment outcome.

The one-visit apexification has several advantages over conventional type. Once the initial infection has resolved, an osteoinductive material can be placed at the root apex to achieve an apical plug. Thereafter, obturation and permanent restoration may be placed. The tooth would subsequently be reviewed periodically for healing. Patient's motivation and compliance plays a minimal role in treatment outcome.

Current osteoinductive materials recommended in apexification are calcium hydroxide and mineral trioxide aggregate (MTA) (4). Calcium hydroxide is manufactured in two forms, powder and paste. Calcium hydroxide powder is manufactured in pure form while paste, its non-setting form, has vehicle and additives added to increase ease of application into the canals. Calcium hydroxide powder has a $\mathrm{pH}$ of 12.6 while paste is slightly lower (5). The exact mechanism is still unclear. The periapical tissues in contact with calcium hydroxide, develop a superficial three-layer necrosis resulting from chemical injury due to the high $\mathrm{pH}$ (6). This area of necrosis causes irritation and stimulates the defense and repair mechanism leading to mineralisation. The high $\mathrm{pH}$ of calcium hydroxide also stimulates mineralisation through activation of tissue enzymes like alkaline phosphatase (ALP) $(7,8)$.

MTA is mainly composed of Portland cement, bismuth oxide and calcium sulphate dehydrate. It is known for its osteoinductive potential (9-15). MTA has an initial $\mathrm{pH}$ of 10.2 and sets at $\mathrm{pH} 12.9$ and remains constant thereafter (16). The high $\mathrm{pH}$ activate ALP in the surrounding tissues as in calcium 
hydroxide. However, the exact mechanism of action differs due to the composition of the materials. Ionic dissociation of MTA releases hydroxyl ions $\mathrm{O}^{2-}$ from tetrahedron silicate and calcium oxide. These larger hydroxyl ions may be less effective against the bacterial cytoplasmic membrane (17), hence, it has a poorer antibacterial property and lower inflammatory response to the surrounding tissues compared to calcium hydroxide.

In brief, the cellular events following an insult/ injury in hard tissue formation generally undergo the following sequence; chemotaxis, proliferation, differentiation, mineralisation of hard tissue matrix and cessation of hard tissue formation activity (18). The presence of ALP is indicative of cells in differentiation phase. ALP liberates free phosphate ions into the organic matrix. These free phosphate ions react with calcium ions in the blood stream to form calcium phosphate precipitate. Calcium phosphate precipitate is a molecular unit of hydroxylapatite (19). ALP is a hydrolytic enzyme with strong relationship to the process of mineralization and a known marker for hard tissue forming cells, osteonectin and osteopontin (20-26). The optimal $\mathrm{pH}$ for its activation is between 8.6 and 10.3 (27). ALP is inhibited at a $\mathrm{pH}$ of $11.9-12.3$ (28).

Though calcium hydroxide has been traditionally used in apexification, no study has been conducted to evaluate its ALP activity. Therefore, the purpose of this study was to assess the ALP activity of MG63 cells on currently recommended osteoinductive materials used in apexification namely calcium hydroxide powder $(\mathrm{CH})$, paste $(\mathrm{CHP})$ and MTA.

\section{MATERIALS AND METHODS}

\section{Cell culture}

MG-63 cell line (American Type Culture Collection; ATCC number: CRL-1427) was obtained from a bone tissue of a 14 year-old Caucasian male. These cells were grown in modified Eagle's Minimal Essential Medium (EMEM). The growth medium was modified EMEM supplemented with $10 \%$ heatinactivated fetal bovine serum while the maintenance medium was modified EMEM supplemented with $2 \%$ heat-inactivated fetal bovine serum. The cells were grown in $75 \mathrm{~cm}^{3}$ sterile tissue culture flasks (Nunc, Germany) and incubated in a humidified atmosphere at a temperature of $37^{\circ} \mathrm{C}$ in $5 \% \mathrm{CO}^{2}$.

\section{Extract preparation}

The test materials used in this study were calcium hydroxide powder Pulpdent ${ }^{\circledR}$, calcium hydroxide paste, Pulpdent ${ }^{\circledR}$ Tempcanal and grey MTA, ProRoot ${ }^{\mathrm{TM}}$. The dental materials were mixed according to their manufacturer's instructions under sterile conditions. With $\mathrm{CH}$ special precautions were taken, a fresh batch was purchased and the weighed material was preheated with a Bunsen burner to ensure calcium carbonate present was converted into calcium hydroxide.

The material extract was prepared by adding $5 \mathrm{mls}$ of maintenance medium for every $1 \mathrm{~g}$ of test material, forming the stock (29). The concentration of test materials used was $20 \mathrm{mg} / \mathrm{ml}$ (10i1). The control used in the experiment was $10 \mathrm{il}$ modified EMEM medium without $2 \%$ heat-inactivated fetal bovine serum. 96-well microtitre plate containing material extracts were seeded with 100 il of suspended MG-63 cells at $1 \times 10^{6}$. Incubation periods were $0.25 \mathrm{~h}, 0.5 \mathrm{~h}, 1 \mathrm{~h}, 24 \mathrm{~h}, 48 \mathrm{~h}$ and $72 \mathrm{~h}$. Three microtitre plates were prepared for the selected durations for each material. The experiment was repeated thrice. The microtitre plates were then placed into an incubator at $37^{\circ} \mathrm{C}$ in $5 \% \mathrm{CO}^{2}$. At the end of the stipulated durations, BCIP-NBT (5Bromo-4chloro-3-indolyl phosphate, toluidine saltNitro blue tetrazolium chloride) Liquid Substrate System (Sigma Aldrich) was used to detect alkaline phosphatase.

$30 \mu \mathrm{l}$ of labeling agent was added into wells in a dark-hood as the labeling agent was photosensitive. Each microtitre plate was wrapped in an aluminium foil and incubated at $37^{\circ} \mathrm{C}$ in $5 \% \mathrm{CO}^{2}$ for 45 minutes. ELISA reader (Dynatech MR5000, Guernsey Channel Island) was used to record the absorbance at $410 \mathrm{~nm}$. The absorbance measured correlated to the number of viable osteoblast cells present. Data obtained were recorded and compiled.

\section{RESULTS}

ALP activity of MG-63 cells has been summarized in Figure 1. The null hypothesis was that the test materials do not exhibit increased ALP activity. Overall analysis indicated significant interaction between test materials and control and that duration was a factor. Test materials were subsequently, paired and analysed for initial $(0.25 \mathrm{~h}, 0.5 \mathrm{~h}$ and $1 \mathrm{~h})$ and delayed response (24h, $48 \mathrm{~h}$ and $72 \mathrm{~h})$. Survival analysis comparing multiple samples statistics, Cox's proportional hazard regression model was used to analyse data and significance level was set at $\mathrm{p} \leq 0.05$.

During the initial response (Figure 1), $\mathrm{CH}$ showed the highest ALP activity followed by CHP and MTA. CH and CHP had similar downward trend while MTA showed a spike in ALP activity at 30 minutes. Only interaction between $\mathrm{CH}$ and MTA was significant $(\mathrm{p}=0.0047)$.

During the delayed response (Figure 1), CHP exhibited a sudden increased activity between 24 and $48 \mathrm{~h}$. CH showed a steep drop from 24 to $48 \mathrm{~h}$ but ALP activity increased thereafter while MTA showed a drop in ALP activity after 48h. The interaction between $\mathrm{CH}$ and $\mathrm{CHP}$ was significant $(\mathrm{p}=0.0510)$ 


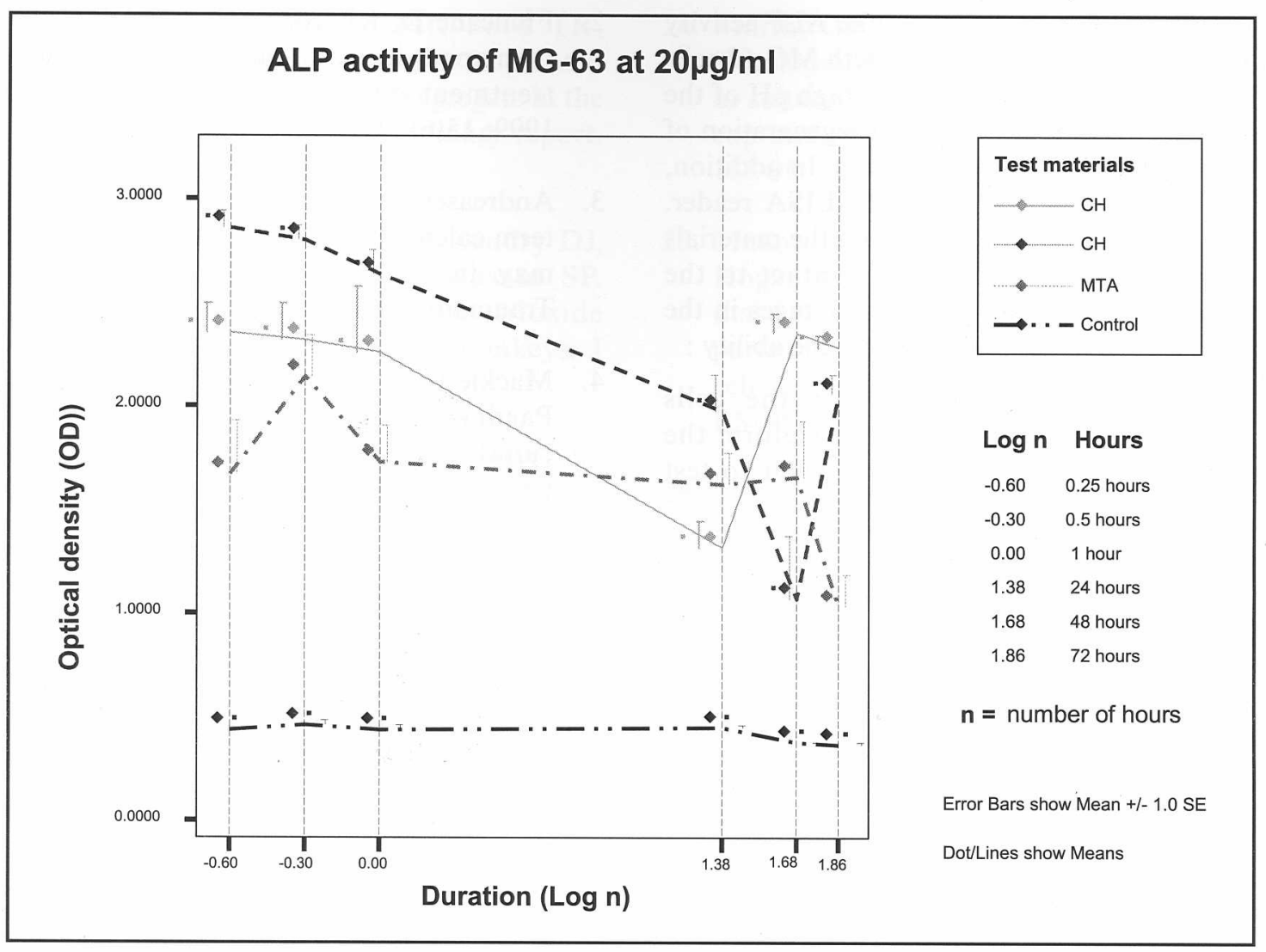

Figure 1. ALP activity of MG-63 of three materials and control.

and duration was a factor $(\mathrm{p}=0.0180)$. However, with CHP and MTA, the interaction between the materials was not significant but duration was a factor $(p=0.0110)$. The interaction between $\mathrm{CH}$ and MTA was not significant.

\section{DISCUSSION}

Todar (30) stated that 10\% FBS contained growth factors that stimulate cell proliferation when added into the flask containing cells. These cells would proliferate exponentially for three or four days until some stimulatory components of the serum was exhausted or depleted. The cells then slip into Go phase (resting) even though the nutrients are still present in the medium.

In this study, maintenance medium was used. Therefore cells entered Go phase and stayed dormant for several days. On induction, the cells in Go phase entered active proliferation and subsequently, cellular differentiation (31). It was noted that after 15 minutes, the number of viable cells was high and ALP activity remained high during the first hour. This may be indicative of cells being in differentiation phase (20). Therefore, the reaction observed in Figure 1 was most likely induced by the materials. Hence, all three materials have shown some osteoinductive potentials. This was in agreement with previous cellular and animal studies (12, 13, 32-42).

During the first hour (initial response phase), ALP activity of $\mathrm{CH}$ and $\mathrm{CHP}$ were similar. This may be due to their similar material composition. Both $\mathrm{CH}$ and $\mathrm{CHP}$ had aqueous vehicles and their biological action was determined by the rate of ionic dissociation of $\mathrm{Ca}^{2+}$ and $\mathrm{OH}^{-}$ions (43). $\mathrm{CH}$ was mixed in sterile distilled water while CHP, a propriety product, contained methylcellulose and other additives. The vehicle used likely altered the behaviour of CHP. Also in vitro, ionic diffusion was also affected by the buffer substances in the culture medium (44). Both these factors contributed to CHP's lower $\mathrm{pH}$ (45) thus its reduced effectiveness when compared to $\mathrm{CH}$.

During the delayed response phase (24-72 hours), there existed constraint of nutrients, accumulation of inhibitory metabolites and biological space. Due to the limited resources available the cells might have slipped into cell death phase (46). By 48 hours, the local environment might not have been conducive for continued cell growth. This was shown by the downward trend by the control cells in Figure 1. Interestingly, between 2472 hours, cell differentiation had begun to accelerate for CHP and $\mathrm{CH}$. CHP showed higher ALP activity compared to $\mathrm{CH}$ and MTA. Further studies should be carried out to investigate this phenomenon. 
This present study investigated the ALP activity when material was in direct contact with MG-63 cells as per clinical application. The initial high $\mathrm{pH}$ of the materials may damage the cells and regeneration of cells through induction may be limited. In addition, the material may interfere with the ELISA reader. Therefore, a valid means of separating the materials from the cells while maintaining contact to the materials would have been ideal. Advantages in the ability to remove the materials include the ability :

- to replace fresh medium for the cells (continuous culture) and therefore the increase the duration of assessment to test materials beyond 48 hours.

- to practise recommendations by Denizot et al (47). Thus enabling a more accurate quantitation by ELISA reader without the interference of the material.

Only one in vitro study conducted with MG-63 cells found no significant increase in ALP activity when MTA was introduced (36). This was not in agreement with present study. However, another researcher (48) found that MTA induced ALP activity in gingival and PDL fibroblasts harvested from patients during removal of the third molar.

\section{CONCLUSION}

This study concluded that calcium hydroxide powder, paste and MTA induced ALP activity in MG-63 cells. Clinically, calcium hydroxide induces healing, unfortunately, the duration for formation of the calcific barrier is however prolonged $(2,4,49)$ with a possibility of increased risk in tooth fracture with long term usage $(3,50)$. Clinical application of MTA in non-vital immature teeth allows the affected tooth to be restored endodontically almost immediately after achieving an apical plug (setting time approximately four hours). Beyond the apical plug, osteoinductive potential of MTA promotes undisturbed formation of the calcific bridge $(35,51)$.

\section{ACKNOWLEDGEMENT}

This research was supported by a grant from University of Malaya, Malaysia (Vote F: F0214/ 2003A).

\section{REFERENCES}

1. Sheehy EC, Roberts GJ. Use of calcium hydroxide for apical barrier formation and healing in non-vital immature permanent teeth: a review. Br Dent J 1997; 183(7): 241-6.
2. Finucane D, Kinirons MJ. Non-vital immature permanent incisors: factors that may influence treatment outcome. Endod Dent Traumatol 1999; 15(6): 273-7.

3. Andreasen JO, Farik B, Munksgaard EC. Longterm calcium hydroxide as a root canal dressing may increase risk of root fracture. Dent Traumatol 2002; 18(3): 134-7.

4. Mackie IC. UK National Clinical Guidelines in Paediatric Dentistry. Management and root canal treatment of non-vital immature permanent incisor teeth. Faculty of Dental Surgery, Royal College of Surgeons. Int J Paediatr Dent 1998; 8(4): 289-93.

5. Estrela C, Pecora JD, Souza-Neto MD, Estrela CR, Bammann LL. Effect of vehicle on antimicrobial properties of calcium hydroxide pastes. Braz Dent J 1999; 10(2): 63-72.

6. Schroder U, Granath LE. Early reaction of intact human teeth to calcium hydroxide following experimental pulpotomy and its significance to the development of hard tissue barrier. Odontol Revy 1971; 22(4): 379-95.

7. Estrela C, Sydney GB, Pesce HF, Felippe Junior $O$. Dentinal diffusion of hydroxyl ions of various calcium hydroxide pastes. Braz Dent J 1995; 6(1): 5-9.

8. Estrela C, Sydney GB, Bammann LL, Felippe Junior O. Mechanism of action of calcium and hydroxyl ions of calcium hydroxide on tissue and bacteria. Braz Dent J 1995; 6(2): 85-90.

9. Germain LP. Mineral trioxide aggregate: a new material for the new millennium. Dent Today 1999; 18(1): 66-7, 70-1.

10. Hatibovic-Kofman S, Raimundo L, Chong L, Moreno J, Zheng L. Mineral trioxide aggregate in endodontic treatment for immature teeth. Conf Proc IEEE Eng Med Biol Soc 2006; 1: 2094-7.

11. Holland R, Filho JA, de Souza V, Nery MJ, Bernabe PF, Junior ED. Mineral trioxide aggregate repair of lateral root perforations. J Endod 2001; 27(4): 281-4.

12. Torabinejad M, Hong CU, Lee SJ, Monsef M, Pitt Ford TR. Investigation of mineral trioxide aggregate for root-end filling in dogs. J Endod 1995; 21(12): 603-8. 
13. Torabinejad M, Hong CU, Pitt Ford TR, Kaiyawasam SP. Tissue reaction to implanted super-EBA and mineral trioxide aggregate in the mandible of guinea pigs: a preliminary report. J Endod 1995; 21(11): 569-71.

14. Torabinejad M, Pitt Ford TR, McKendry DJ, Abedi HR, Miller DA, Kariyawasam SP. Histologic assessment of mineral trioxide aggregate as a root-end filling in monkeys. J Endod 1997; 23(4): 225-8.

15. Abedi HR, Ingle JI. Mineral trioxide aggregate: a review of a new cement. J Calif Dent Assoc 1995; 23(12): 36-9.

16. Estrela C, Bammann LL, Estrela CR, Silva RS, Pecora JD. Antimicrobial and chemical study of MTA, Portland cement, calcium hydroxide paste, Sealapex and Dycal. Braz Dent J 2000; 11(1): 39.

17. Weidmann G, Lewis P, Reid N. Structural materials. Oxford: Butterworth-Heinemann Ltd; 1994.

18. Mundy GR, Boyce B, Hughes D, Wright K, Bonewald L, Dallas S, et al. The effects of cytokines and growth factors on osteoblastic cells. Bone 1995; 17(2 Suppl): 71S-5S.

19. Seltzer S, Bender IB, Hacke G. The dental pulp: Biologic Considerations in Dental Procedures. $3^{\text {rd }}$ edition. Philadelphia Ishiyaku EuroAmerica Inc; 1990.

20. Strauss PG, Closs EI, Schmidt J, Erfle V. Gene expression during osteogenic differentiation in mandibular condyles in vitro. J Cell Biol 1990; 110(4): 1369-78.

21. Nomura S, Wills AJ, Edwards DR, Heath JK, Hogan BL. Developmental expression of 2ar (osteopontin) and SPARC (osteonectin) RNA as revealed by in situ hybridization. J Cell Biol 1988; 106(2): 441-50.

22. Terao M, Mintz B. Cloning and characterization of a cDNA coding for mouse placental alkaline phosphatase. Proc Natl Acad Sci U S A 1987; 84(20): 7051-5.

23. Yoon K, Buenaga R, Rodan GA. Tissue specificity and developmental expression of rat osteopontin. Biochem Biophys Res Commun 1987; 148(3): 1129-36
24. Murthy GP, Rajalakshmi R, Ramakrishnan CV. Developmental pattern of alkaline phosphatase in soluble and particulate fractions of rat skull cap and femur. Calcif Tissue Int 1986; 39(3): $185-90$.

25. Mason IJ, Taylor A, Williams JG, Sage H, Hogan BL. Evidence from molecular cloning that SPARC, a major product of mouse embryo parietal endoderm, is related to an endothelial cell 'culture shock' glycoprotein of $\mathrm{Mr} 43,000$. EMBO J 1986; 5(7): 1465-72.

26. Stenner DD, Tracy RP, Riggs BL, Mann KG. Human platelets contain and secrete osteonectin, a major protein of mineralized bone. Proc Natl Acad Sci USA 1986; 83(18): 6892-6.

27. Hunt SW, Thompson RD. Selected Histochemical and Histopathical Methods. Charles C. Thomas; 1966.

28. Gordon TM, Ranly DM, Boyan BD. The effects of calcium hydroxide on bovine pulp tissue: variations in $\mathrm{pH}$ and calcium concentration. $\mathbf{J}$ Endod 1985; 11(4): 156-60.

29. Zhang M, Powers RM, Jr., Wolfinbarger L, Jr. A quantitative assessment of osteoinductivity of human demineralized bone matrix. J Periodontol 1997; 68(11): 1076-84.

30. Todar K. Growth of bacterial populations. Online reference-http://www.textbookofbacterio logy.net; 2007.

31. Yamamura T. Differentiation of pulpal cells and inductive influences of various matrices with reference to pulpal wound healing. J Dent Res 1985; 64 Spec No: 530-40.

32. Granchi D SS, Ciapetti G, Cavedagna D, Stea S, Pizzoferrato A. Endodontic cements induce alterations in the cell cycle of in vitro cultured osteoblasts. Oral Surg Oral Med Oral Pathol Oral Radiol Endod 1995; 79(3): 359-66.

33. Torabinejad M, Smith PW, Kettering JD, Pitt Ford TR. Comparative investigation of marginal adaptation of mineral trioxide aggregate and other commonly used root-end filling materials. J Endod 1995; 21(6): 295-9.

34. Torabinejad M, Rastegar AF, Kettering JD, Pitt Ford TR. Bacterial leakage of mineral trioxide aggregate as a root-end filling material. J Endod 1995; 21(3): 109-12. 
35. Ford TR, Torabinejad M, Abedi HR, Bakland LK, Kariyawasam SP. Using mineral trioxide aggregate as a pulp-capping material. J Am Dent Assoc 1996; 127(10): 1491-4.

36. Koh ET, Torabinejad M, Pitt Ford TR, Brady K, McDonald F. Mineral trioxide aggregate stimulates a biological response in human osteoblasts. J Biomed Mater Res 1997; 37(3): 432-9.

37. Holland R, de Souza V, Nery MJ, Otoboni Filho JA, Bernabe PF, Dezan Junior E. Reaction of rat connective tissue to implanted dentin tubes filled with mineral trioxide aggregate or calcium hydroxide. J Endod 1999; 25(3): 161-6.

38. Holland R, de Souza V, Nery MJ, Faraco Junior IM, Bernabe PF, Otoboni Filho JA, et al. Reaction of rat connective tissue to implanted dentin tube filled with mineral trioxide aggregate, Portland cement or calcium hydroxide. Braz Dent J 2001; 12(1): 3-8.

39. Mitchell PJ, Pitt Ford TR, Torabinejad M, McDonald F. Osteoblast biocompatibility of mineral trioxide aggregate. Biomaterials 1999; 20(2): 167-73.

40. Shabahang S, Torabinejad M, Boyne PP, Abedi H, McMillan P. A comparative study of rootend induction using osteogenic protein-1, calcium hydroxide, and mineral trioxide aggregate in dogs. J Endod 1999; 25(1): 1-5.

41. Abdullah D, Pitt Ford TR, Papaioannou S, Nicholson J, McDonald F. An evaluation of accelerated Portland cement as a restorative material. Biomaterials 2002; 23(19): 4001-10.

42. Huang TH, Ding SJ, Hsu TC, Kao CT. Effects of mineral trioxide aggregate (MTA) extracts on mitogen-activated protein kinase activity in human osteosarcoma cell line (U2OS). Biomaterials 2003; 24(22): 3909-13.
43. Fava LR, Saunders WP. Calcium hydroxide pastes: classification and clinical indications. Int Endod J 1999; 32(4): 257-82.

44. Siqueira JF, Jr., Lopes HP. Mechanisms of antimicrobial activity of calcium hydroxide: a critical review. Int Endod J 1999; 32(5): 361-9.

45. Estrela C, Pimenta FC, Ito IY, Bammann LL. In vitro determination of direct antimicrobial effect of calcium hydroxide. J Endod 1998; 24(1): 157.

46. Moghaddame-Jafari S, Mantellini MG, Botero TM, McDonald NJ, Nor JE. Effect of ProRoot MTA on pulp cell apoptosis and proliferation in vitro. J Endod 2005; 31(5): 387-91.

47. Denizot F, Lang R. Rapid colorimetric assay for cell growth and survival. Modifications to the tetrazolium dye procedure giving improved sensitivity and reliability. J Immunol Methods 1986; 89(2): 271-7.

48. Bonson S, Jeansonne BG, Lallier TE. Root-end filling materials alter fibroblast differentiation. $\mathrm{J}$ Dent Res 2004; 83(5): 408-13.

49. Cvek M. Treatment of non-vital permanent incisors with calcium hydroxide. I. Follow-up of periapical repair and apical closure of immature roots. Odontol Revy 1972; 23(1): 27-44.

50. Andreasen JO, Munksgaard EC, Bakland LK. Comparison of fracture resistance in root canals of immature sheep teeth after filling with calcium hydroxide or MTA. Dent Traumatol 2006; 22(3): 154-6.

51. Koh ET, McDonald F, Pitt Ford TR, Torabinejad M. Cellular response to Mineral Trioxide Aggregate. J Endod 1998; 24(8): 543-7. 